Bulgarian Academy of Sciences. Space Research and Technology Institute. Aerospace Research in Bulgaria. 33, 2021, Sofia

DOI: https://doi.org/10.3897/arb.v33.e19

This article is written in honour of Yuri Gagarin, Celebrated around the world every year on April 12.

\title{
ADVANCES IN SPACE SCIENCE AND TECHNOLOGY IN CONNECTION WITH 60-TH ANNIVERSARY OF FIRST HUMAN SPACEFLIGHT
}

\author{
Peter Velinov \\ Space Research and Technology Institute - Bulgarian Academy of Sciences \\ e-mail: pvelinov@bas.bg
}

Keywords: Yuri Gagarin, First Human Spaceflight, Space Science, Space Exploration

\begin{abstract}
On April 12, 1961, Yuri Gagarin proclaimed the arrival of a new space age. The rapid advances in the different space sciences and technologies began after the first human spaceflight. Then, fundamentally new sciences and technologies appeared. At present, space science covers a broad range of disciplines. The following outline is provided as an overview and topical guide to space sciences:

Astronomy and Space Astronomy, Cosmology, Astrophysics, Space Physics, SolarTerrestrial Physics, Aeronomy, Solar physics, Heliospheric Physics, Cosmic Ray Physics, Space Weather and Space Climate (Earth-Space Climatology), Space Dosimetry, Space Chemistry or Cosmochemistry, Remote Sensing of the Earth and Planets, Planetary Science, Planetary Geology, Astrogeology or Exogeology, Exoplanetology or Exoplanetary Science (Science for Extrasolar Planetary Systems), Intelligent Life in the Universe, Astronautics (or Cosmonautics), Orbital mechanics or Astrodynamics, Space life sciences: Bioastronautics, Space Medicine, Space Neuroscience, Space Biology, Radiation Biology, Biotechnology, Space Botany or Astrobotany, Microgravity Environment Research; Archaeoastronomy, Space Anthropology, Xeno-anthropology (Exo-anthropology), Space Law, Space Technology, Space Navigation, Space Communications, Space Architecture, Space Logistics, Space Robotics, Space Robotic Colonies, Space Colonization (also called Space Settlement or Extraterrestrial Colonization), Planetary Habitability, Space Manufacturing, Space Materials Science, Satellite Industry, Space Business, Space Tourism, Space Hardware, Space Industry, and Space Ecology.

With the help of these advanced space sciences humankind confidently began the exploration of space. But these studies led also to numerous new technologies and applications to improve people's lives.

Finally, we mention again Yuri Gagarin and his cosmic heritage. He left behind an inspirational legacy, which even today still continues to motivate millions of people worldwide.
\end{abstract}




\section{Introduction}

On October 4, 1957, the first human-made Earth satellite Sputnik I was launched into outer space, thus opening the way for space exploration. On April 12, 1961, Yuri Gagarin became the first human to orbit the Earth, opening a new chapter of human endeavour in outer space.

The Declaration of General Assembly of United Nations (UN) of April 7, 2011 recalls "the amazing history of human presence in outer space and the remarkable achievements since the first human spaceflight, in particular Valentina Tereshkova becoming the first woman to orbit the Earth on June 16, 1963, Neil Armstrong becoming the first human to set foot upon the surface of the Moon on July 20, 1969, and the docking of the Apollo and Soyuz spacecrafts on July 17, 1975 , being the first international human mission in space, and recall that for the past decade humanity has maintained a multinational permanent human presence in outer space aboard the International Space Station.”

\section{The beginning of the Space Era for mankind}

The 12 April 1961 was the date of the first human space flight, carried out by Yuri Gagarin (Figs. 1, 2), a Soviet citizen. This historic event opened the way for space exploration for the benefit of all humanity.

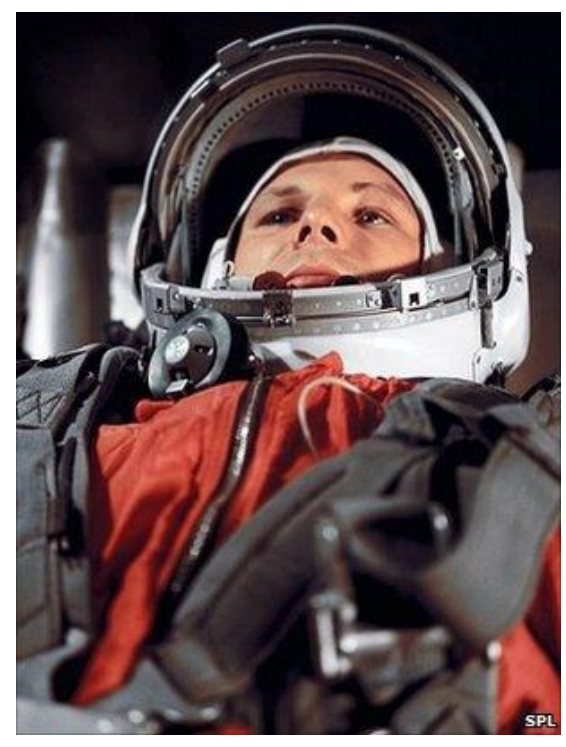

Fig. 1. Gagarin's name was immortalised when he made a single orbit of Earth on April 12, 1961. (Science reporters, BBC News, https://www.bbc.com/news/science-environment12460720) 


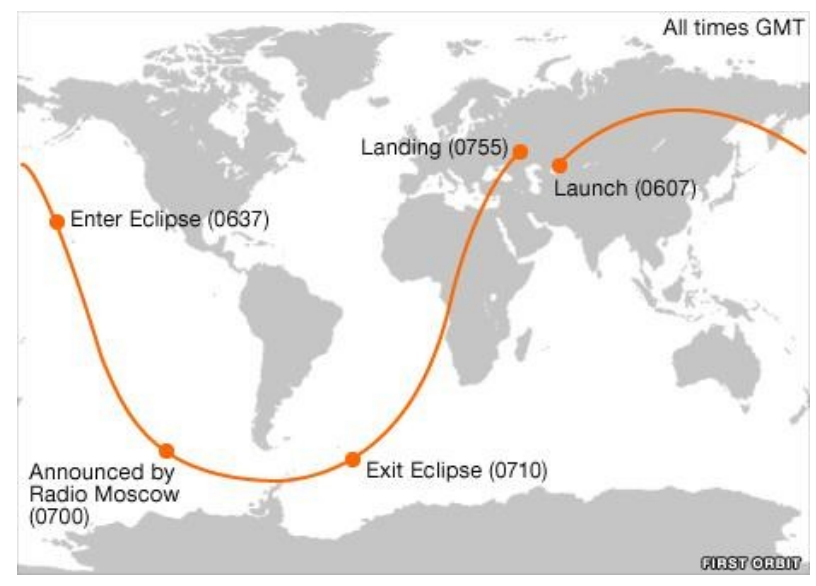

Fig. 2. The trajectory of the spacecraft „Vostok-1 “. Gagarin went into darkness behind the Earth over the Pacific. He saw the Sun rise as he was moving over the South Atlantic. (Science reporters, BBC News, https://www.bbc.com/news/science-environment-12460720)

The General Assembly of UN, in its resolution A/RES/65/271 of April 7, 2011, further declared 12 April as the International Day of Human Space Flight "to celebrate each year at the international level the beginning of the space era for mankind, reaffirming the important contribution of space science and technology in achieving sustainable development goals and increasing the well-being of States and peoples, as well as ensuring the realisation of their aspiration to maintain outer space for peaceful purposes."

The General Assembly expressed its deep conviction of the common interest of mankind in promoting and expanding the exploration and use of outer space, as the province of all mankind, for peaceful purposes and in continuing efforts to extend to all States the benefits derived there from.

\section{UN and Space}

From the very beginning of the Space Age, the United Nations recognised that outer space added a new dimension to humanity's existence. The United Nations family strives continuously to utilise the unique benefits of outer space for bettering all humankind.

Today, the United Nations work for international cooperation in peaceful uses of outer space with the United Nations Committee on the Peaceful Uses of Outer Space (COPUOS).

This Committee is also responsible for implementing the SecretaryGeneral's responsibilities under international space law and maintaining the United Nations Register of Objects Launched into Outer Space. 
The United Nations has approved for the international community the following periods related to space:

- International Day of Human Space Flight (12 April);

- World Space Week (4 - 10 October), associated with the celebration of the first artificial satellite Sputnik I;

- International Asteroid Day (30 June);

- International Space Year ISY (1992).

\section{Space Science and Exploration}

Space science makes us look outwards from our planet, to the stars and beyond. It's a subject who strives to answer the ultimate questions: How did our Earth and our Solar System form and evolve? What is our place in the Universe? Where are we going? Where did life come, and are we alone?

By studying the other planets in our own Solar System, we can try placing Earth in context. The space states, organizations and institutes, for instance: NASA, RosCosmos, CNSA (China National Space Administration), ESA, JAXA (Japan Aerospace Exploration Agency), etc. have already sent the spacecraft to Earth's nearest planetary neighbours - Mars and Venus - to understand why they evolved so differently, and in the next decade we'll be unlocking the secrets of the innermost planet, Mercury, too.

The gas giants, and in particular Jupiter with its four large moons - some of which may harbour underground oceans - is also a key to piece together the Solar System evolution. Unravelling the behaviour of our parent star, the Sun, is another crucial element to decipher our cosmic origins. And as more and more planets are found orbiting other stars, understanding our own cosmic neighbourhood has never been important.

What about the origin of the Universe itself? If we could 'see' microwaves, the night sky would glow with the first light ever released into space. This is the relic radiation of the Big Bang - the event that set the beginning to the Universe itself. With our space science missions we can tease out the details of the Universe's earliest moments, seek out the first stars and galaxies, and learn about the fabric of space and time.

These incredible space observatories can also give us clues to the future destiny of our Milky Way galaxy, and the Universe itself. The space science missions provide access to the largest science laboratory we have ever known: our Universe.

\section{Overview of space sciences}

Thousands of years ago, our remote ancestors looked up and wondered about their place between Earth and sky. Like them, we ask the same profound questions, such as how did the universe begin? 
Today, we are beginning to answer these questions. Using tools of science that range from abstract mathematics and computer modelling to laboratories and observatories, humans are filling in the details of the amazing storey of the universe.

In the last 60 years, space probes and space observatories have played a central role in this fascinating process, and RosCosmos, ESA, NASA, CNSA, JAXA, etc. Space Science agencies will continue to address these four profound questions:

1) How did the universe begin and evolve? We seek to, explain the earliest moments of the universe, how stars and galaxies formed, and how matter and energy are entwined on the grandest scales.

2) How did we get here? We investigate how the chemical elements necessary for life have been built up and dispersed throughout the cosmos, evidence about how the Sun affects Earth, similarities between Earth and other planets, and how comets and asteroids in our solar system affect Earth.

3) Where are we going? Our ultimate place in the cosmos is wrapped up in the fate of the universe. Humanity has taken its first steps off our home world, and we will make it safe to travel throughout the solar system.

4) Are we alone? Beyond astrophysics and cosmology, there lies the central human question: Are we on Earth because of an improbable accident of nature? Or is life, perhaps even intelligent life, scattered throughout the cosmos?

Now, in support of the new vision of space exploration, orbiting observatories and planetary probes will be joined by human explorers in seeking answers to these questions. Robotic scouts will blaze the trail, reconnoitring the planets, moons, asteroids, and comets of the solar system in advance of human expeditions, as observatories monitor the sun and its effects on its planetary retinue.

The Space Science will work with new exploration systems to develop and deploy new technologies, first on automated spacecraft and then on human missions.

\section{Branches of Space sciences}

Space science covers a broad range of disciplines, from meteorology and geology, to lunar, solar, and planetary science, to astronomy and astrophysics, to the life sciences. Space science encompasses all of the scientific disciplines that involve space exploration and study natural phenomena and physical bodies occurring in outer space, such as space medicine and space biology $[1,2]$.

The following outline is provided as an overview and topical guide to space science:

Astronomy - sciences that study the laws of the stars are a natural science that studies celestial objects and phenomena. It uses mathematics, physics, and 
chemistry to explain their origin and evolution. Objects of interest include sun, moon, planets, stars, nebulae, galaxies, comets, gas, dust and other non-Earthly bodies and phenomena. Relevant phenomena include supernova explosions, gamma ray bursts, quasars, blazars, pulsars, and cosmic microwave background radiation. More generally, astronomy studies everything that originates outside Earth's atmosphere. Cosmology is a branch of astronomy. It studies the Universe as a whole.

Space Astronomy is engaged now in observational research from instruments for the next generation and the study and launch of new improved space missions. Observations are conducted over a wide range of wavelengths, including radio submillimeter infra-red, X-ray and gamma-rays. Main targets include galaxy clusters, active galactic nuclei, galaxies, stars star-forming regions and protostars, supernova remnants, interstellar matter, exoplanets.

Astrophysics - study of the physics of the universe; of extraterrestrial objects and interstitial spaces. Astrophysics refers to the branch of astronomy dealing with the behaviour, physical properties, and dynamic processes of celestial objects and phenomena. For astrophysics are especially important results and experiments in space astronomy.

Space Physics studies physical processes and phenomena in outer space. Space physics is distinct from astrophysical plasma and the field of astrophysics, which studies similar plasma phenomena beyond the Solar System. Space physics utilises in situ measurements from rockets and spacecraft [1-3] in contrast to astrophysical plasma that relies on the deduction of theory and astronomical observation.

Solar-Terrestrial Physics, is the study of plasmas as they occur naturally in the Earth's environment - upper atmosphere (aeronomy) and within the Solar System [3].

Space physics and solar-terrestrial physics encompass a far-ranging number of topics, such as heliophysics, which includes the solar physics of the Sun [4]: the solar wind, planetary magnetospheres and ionosphere, galactic and solar cosmic rays [5-8], auroras, high energetic particles and fields, cosmic electrodynamics and synchrotron radiation [9-15].

Heliospheric physics research into the heliospheric structure and its relation to the solar boundary, also behavior of the heliospheric magnetic field and the solar wind. The heliospheric community search a progress towards a predictive model describing the connections between the Sun and its space environment, between the closed corona and the open corona extending to the planets. This requires an understanding of the basic processes heating the corona and transporting open magnetic field [1].

Space physics, space geophysics and solar-terrestrial physics are a fundamental part of the study of space weather and space climate (Earth-Space climatology) and has important implications in not only to understanding the 
universe, but also for practical everyday life, including the biomedical problems related to human health, environmental radiation, geomagnetic storms, operations of communications and weather satellites [16].

Cosmic ray physics - cosmic ray story begins at the beginning of $\mathrm{XX}$ century (they are discovered in 1912 by Victor Hess). More than 100 years later, most of the main issues are still open questions, as sources, acceleration mechanism, propagation and composition [17-21].

The search for a theory of the origin of cosmic rays that may be considered a standard agreeable model is still ongoing. However, much circumstantial evidence exists of the fact that supernovae in our Galaxy play a crucial role in producing the bulk of cosmic rays observed on Earth. Whether the maximum energy of light nuclei is as high as $1000 \mathrm{TeV}$ has important consequences on the crucial issue of the transition from Galactic to extragalactic cosmic rays.

Space Dosimetry. Cosmonauts (astronauts) in space are exposed to a radiation environment that can have deleterious health consequences. This environment is both complex (trapped electrons and protons, galactic cosmic ray GCR - ions, secondary charged fragments, and neutrons) and dynamic (changing in time and orbital location). The probabilities of adverse health effects - the health risks of space radiation - cannot be measured directly, but must be calculated [22, 23].

Space chemistry or cosmochemistry is a relatively recent area of specialisation compared to astrophysics. Astrochemistry is the study of the abundance and reactions of molecules in the Universe, and their interaction with radiation. The discipline is an overlaps of astronomy and chemistry $[3,21]$.

Remote Sensing of the Earth and Planets is the acquisition of information about an object or phenomenon without making physical contact with the object and thus is in contrast to the on-site observation. The term is applied especially to acquiring information about the Earth. Remote sensing is used in numerous fields, including geography, land surveying and most Earth science disciplines (for example, hydrology, ecology, meteorology, oceanography, glaciology, geology); it also has a military, intelligence, commercial, economic, planning, and humanitarian applications, among others.

Planetary Science is the study of the assemblage of planets, moons, dwarf planets, comets, asteroids, and other bodies orbiting the Sun, as well as extrasolar planets. The Solar System has been relatively well-studied, initially through telescopes and then later by spacecrafts. This has provided a good overall understanding of the formation and evolution of the Sun's planetary system, although many new discoveries are still being made.

Planetary Geology, alternatively known as Astrogeology or Exogeology, is a planetary science discipline concerned with the geology of the celestial bodies such as the planets and their moons. 
Exoplanetology, or Exoplanetary Science (Science for Extrasolar Planetary Systems), is an integrated field of space science dedicated to the search for and study of exoplanets (extrasolar planets). It employs an interdisciplinary approach that includes astronomy, astrophysics and space physics, cosmochemistry, space geology, geochemistry, space biology, and planetary science.

Astronautics (or Cosmonautics) are the theory and practise of travel beyond Earth's atmosphere into outer space. Spaceflight is one of its main applications and space science its overarching field. Actual astronautics is the science and engineering of spacefaring and spaceflight, a subset of Aerospace engineering (which includes atmospheric flight) $[1,2]$.

Orbital mechanics or Astrodynamics, are the application of ballistics and celestial mechanics to the practical problems concerning the motion of rockets and other spacecraft. The motion of these objects is usually calculated from Newton's laws of motion and law of universal gravitation. Orbital mechanics are a core discipline within space-mission design and control.

Space life sciences:

Bioastronautics is a specialty area of biological and astronautical research , which encompasses numerous aspects of biological, behavioral, and medical concern governing humans and other living organisms in a space flight environment; and includes the design of payloads, space habitats, and life-support systems. In short, it spans the study and support of life in space.

Space Medicine is the practice of medicine on astronauts in outer space whereas astronautical hygiene is the application of science and technology to the prevention or control of exposure to the hazards that may cause astronaut ill health. Both these sciences work together to ensure that astronauts work in a safe environment. The main objective is to discover how well and for how long people can survive the extreme conditions in space $[1,22]$.

Space Neuroscience is the scientific study of the central nervous system (CNS) functions during spaceflight. Living systems can integrate the inputs from the senses to navigate in their environment and to coordinate posture, locomotion, and eye movements. Gravity plays a fundamental role in controlling these functions. In weightlessness during spaceflight, integrating the sensory inputs and coordinating motor responses is harder to do because gravity is no longer sensed during free-fall [1].

Space Biology Research in Space Biology is aimed at addressing the basic questions regarding the extent to which gravity plays a role in growth, morphology, and function of cells in the space environment (Cell Biology), and from the early development of animals and plants to several life cycles (Developmental Biology). A more applied aspects of Space Biology research also include the biological effects of space radiation and radiation standards (Radiation Biology) and the production of cells for medically valuable proteins (Biotechnology) [1]. 
Space Botany or Astrobotany is an applied sub-discipline of botany that is the study of plants in space environments. It is a branch of astrobiology and botany. It has been a subject of study that plants may be grown in outer space typically in a weightless but pressurised controlled environment in specific space gardens. In the context of human spaceflight, they can be consumed as food and/or provide a refreshing atmosphere. Plants can metabolise carbon dioxide in the air to produce valuable oxygen, and can help control cabin humidity. Growing plants in space may provide a psychological benefit to human spaceflight crews.

Micro-g Environment Research. The term micro-g environment (also $\mu \mathrm{g}$, often referred to by the term Microgravity) is more or less synonymous with the terms weightlessness. The most commonly known microgravity environment can be found aboard the International Space Station (ISS) which is located in low-earth orbit at an altitude of around $400 \mathrm{~km}$, orbiting Earth around 15 times per day in what is considered free fall [1].

Archaeoastronomy is the interdisciplinary or multidisciplinary study of how people in the past have understood the phenomena in the sky, how they used these phenomena and what role the sky played in their cultures.

Space Anthropology is a sub discipline of anthropology that looks at all human responses to and interactions with Space; from Archaeo-astrology to Xenoanthropology (Exo-anthropology) we bring together all different areas of study surrounding humans and Space to better understand where we might be heading in the future.

Space Law is the body of law governing space-related activities, encompassing both international and domestic agreements, rules, and principles.[1] Parameters of space law include space exploration, liability for damage, weapons use, rescue efforts, environmental preservation, information sharing, new technologies, and ethics.

Space Technology is a technology developed by space science for use in astronautics, for purposes such as spaceflight or space exploration. Space technology includes spacecraft, satellites, space stations, and support infrastructure equipment, and procedures and space warfare. Space is such a novel environment that attempting to work in it requires new tools and techniques. Many common everyday services such as weather forecasting, remote sensing, satellite navigation systems, satellite television, and some long-distance communication systems critically rely on space infrastructure.

Of the sciences, astronomy and Earth science benefit from space technology [1]. New technologies originating with or accelerated by space-related endeavours are often subsequently exploited in other economic activities.

Space Navigation - today's spacecraft demand complex guidance and navigation control solutions that are safe, low risk, low cost and reliable. 
Space navigators had to invent a new science of space navigation, using star sightings, precise timing, and radio communications. The great distance spacecraft had to travel called for even greater precision in timing and positioning than ever before.

A Deep-Space Positioning System (DPS) has been developed for this purpose. DPS is a single device that provides a spacecraft's position and velocity in interplanetary space.

Space Communications to and from space is a challenging endeavour [2428]. Fortunately, we have the experience and expertise to get space data to the ground. The Space Communications and Navigation ( $\mathrm{SCaN}$ ) programme enables this data exchange, whether it's with cosmonauts aboard the International Space Station, rovers on Mars, or the missions to the Moon.

Man's greatest achievement in this regard is the Voyager spacecraft launched in 1977, that 44 years later is still communicating with Earth from more than 180 billion km away and has far outlived even the most optimistic projections of longevity.

Space Architecture is the theory and practice of designing and building inhabited environments in outer space.[1] The architectural approach to spacecraft design addresses the total built environment. It is mainly based on the field of engineering (especially aerospace engineering), but also involves diverse disciplines such as space physiology, psychology, and sociology. Like architecture on Earth, the attempt is to go beyond the component elements and systems and gain a broad understanding of the issues that affect design success.

Space Logistics is the theory and practice of driving space system design for operability and of managing the flow of material, services, and information needed throughout a space system lifecycle.

However, this definition in its larger sense includes terrestrial logistics in support of space travel, including any additional "design and development, acquisition, storage, movement, distribution, maintenance, evacuation, and disposition of space materiel", movement of people in space (both routine and for medical and other emergencies), and contracting and supplying any required support services for maintaining space travel.

Space Robotics - In the space community, any unmanned spacecraft can be called a robotic spacecraft. However, Space Robots are deemed more capable devices that can facilitate manipulation, assembling, or servicing functions in orbit as assistants to astronauts, or to extend the areas and abilities of exploration on remote planets as surrogates for human explorers.

Space Robotic Colonies are perhaps one of the most advanced and exciting areas of today's space robotic research and technology development. A robotic colony provides a permanent, continuous operational presence elsewhere in our solar system. Established and operated by robots, possibly visited by humans - 
eventually perhaps populated by both - a colony is established, expanded and resupplied using resources from Earth, and native, in situ resources.

Space Colonization (also called Space Settlement or Extraterrestrial Colonization) is the hypothetical permanent habitation and exploitation of natural resources from outside planet Earth. As such it is a form of human presence in space, beyond human spaceflight or operating space outposts.

Planetary Habitability is the measure of a planet's or a natural satellite's potential to develop and maintain environments hospitable to life. Life may be generated directly on a planet or satellite endogenously or be transferred to it from another body, through a hypothetical process known as panspermia.

Space Manufacturing - In-Space Manufacturing (ISM) involves a comprehensive set of processes aimed at the production of manufactured goods in the space environment. ISM is also often used interchangeably with the term inorbit manufacturing given that current production capabilities are limited to low Earth orbit.

There are some rationales supporting in-space manufacturing, f.e.: the space environment, in particular the effects of microgravity and vacuum, enable the research of and production of goods that could otherwise not be manufactured on Earth.

Space Materials Science studies microstructure formation during casting of technical alloys under diffusive and magnetically controlled convective conditions. The experimental results with parametric studies using numerical simulations can be used to optimise industrial casting processes [1].

Space Industry refers to economic activities related to manufacturing components that go into Earth's orbit or beyond, delivering them to those regions, and related services. Owing to the prominence of the satellite-related activities, some sources use the term Satellite Industry interchangeably with the term space industry. The term Space Business has also been used. A narrow definition encompasses only hardware providers (primarily related to launch vehicles and satellites). This definition does not exclude certain activities, such as Space Tourism. Thus, more broadly, space industry can be described as the companies involved in the Space Economy, and providing goods and services related to space. Space economy has been defined as "all public and private actors in developing and providing space-enabled products and services. It comprises a long valueadded chaining, starting with research and development actors and manufacturers of Space Hardware and ending with the providers of space-enabled products and services to final users.

\section{Yuri Gagarin and his cosmic heritage}

One of the most inspiring figures in spaceflight history is Yuri Gagarin - a Russian pilot and cosmonaut, the first human in space. 
Yuri Gagarin left behind an inspirational legacy, which still continues to motivate millions to this day. Yuri's Night is celebrated every year on his launch date, the 12th of April, worldwide to honour the milestone Yuri Gagarin set as being the first human in space and inspiring those who came after him. Yuri's Night was founded in 2001 (on occasion of the 40-th anniversary of first human spaceflight) and attracting thousands of celebrants each year.

NASA's Apollo 11, the first mission to put people on the moon, landed in July 1969, and the crew left behind a commemorative medallion - memorial plaque bearing Gagarin's name (Fig. 3).

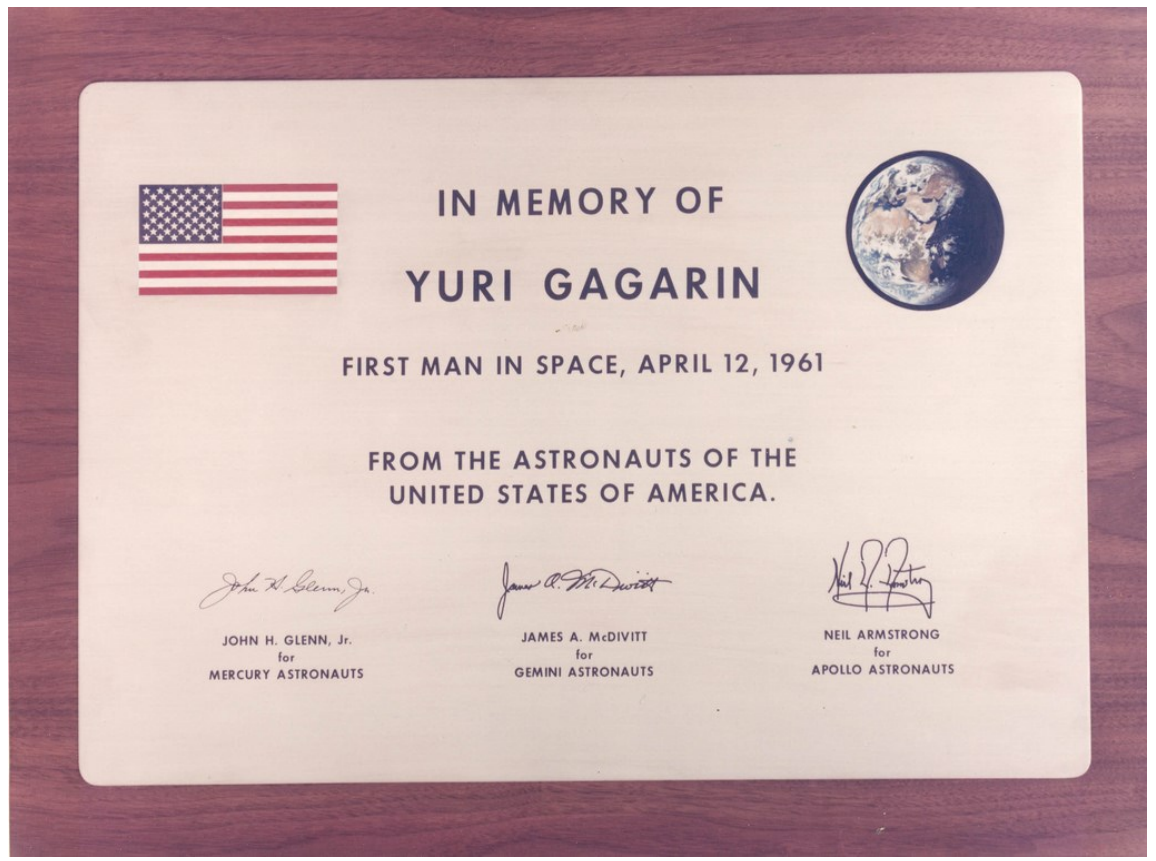

Fig. 3. A memorial plaque commemorating Yuri Gagarin as the first human in space. Image source: Flickr.

The plaque was signed by astronauts of USA: Neil Armstrong (the first man landing on the Moon, July 20, 1969), for the astronauts of the Apollo spacecraft;

James A. McDivitt - for astronauts from the Gemini spacecraft (1965-1966); and by John H. Glenn (the first American astronaut to orbit the Earth February 20, 1962) - for the crews of the Mercury spacecrafts.

The plaque was signed by astronauts of USA: Neil Armstrong (the first man landing on the Moon, July 20, 1969), for the astronauts of the Apollo spacecraft; James A. McDivitt - for astronauts from the Gemini spacecraft (1965- 
1966); and by John H. Glenn (the first American astronaut to orbit the Earth February 20, 1962) - for the crews of the Mercury spacecraft (Fig. 3).

Over time, the U.S. and the Soviet Union began to work together in their spaceflight endeavours. The first joint U.S.-Soviet spaceflight was in 1975, called Apollo-Soyuz. Following that, NASA sent several space shuttle astronauts to Soviet/Russian space station Mir. The shuttle-Mir collaboration paved the way for NASA and the Russian space agency (RosCosmos) to become major partners in the International Space Station programme, which first launched modules in 1998 and continues research today.

Gagarin's importance in the Russian space programme continues. Crews using the Soyuz spacecraft participate in a number of prelaunch traditions prior to climbing on to the spacecraft, to follow in the footsteps of Gagarin's historic flight. Beyond that, Gagarin is often held up as an example of character and heroism to younger children in Russia.

The date of Gagarin's space flight, 12 April, has been commemorated. Since 1962, it has been celebrated in the USSR and most of its former territories as Cosmonautics Day.

There are statues of Gagarin and monuments to him in a number of places around the world (including the United States and Great Britain).

In 2011 (on occasion of the 50-th anniversary of first human spaceflight), a statue of Gagarin was unveiled at the Admiralty Arch in The Mall in London, opposite the permanent sculpture of James Cook. In 2013, the statue was moved to a permanent location outside the Royal Observatory, Greenwich (Fig. 4).

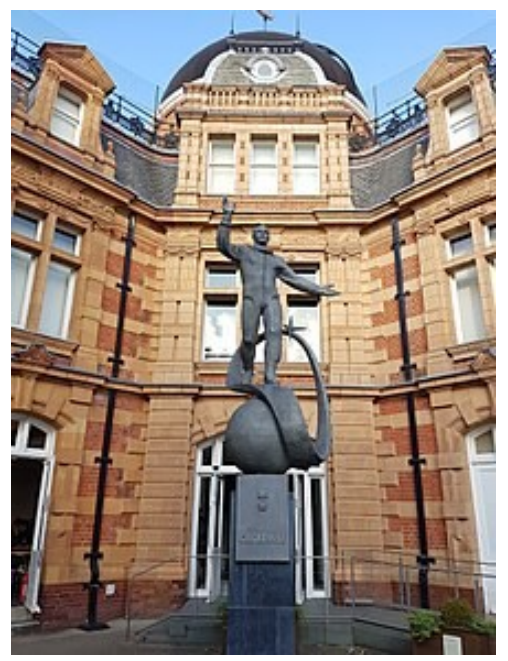

Fig. 4. Yuri Gagarin statue at the Royal Greenwich Observatory in London. https://www.rmg.co.uk/royal-observatory/attractions/yuri-gagarin-statue 
In 2012, a new statue of Gagarin was unveiled at the site of NASA's original spaceflight headquarters in Houston. In April 2018, a bust of Gagarin erected on the street in Belgrade, Serbia, that bears his name.

Numerous streets, boulevards and squares around the world are also named after Gagarin.

\section{References}

1. Serafimov, K., Space Research in Bulgaria, Sofia, BAS Publishing House, 1979, 221 p.

2. Mishev, D., History of Space Research in Bulgaria, Sofia, BAS Publishing House, 2004, $234 \mathrm{p}$.

3. Velinov, P. I. Y., G. Nestorov, L. I. Dorman, Cosmic Ray Influence on the Ionosphere and on Radiowave Propagation, Sofia, BAS Publishers, 1974, ISBN:4897, 314 p.

4. Velinov, P. I. Y., Nestorov G., Effect of solar flares on the low ionosphere. C. R. Acad. Bulg. Sci., 1967, 20, 293-96.

5. Velinov, P. I. Y., A formula derivation for electron production rate in theionosphere under the influence of cosmic rays, C. R. Acad. Bulg. Sci., 1966, 19, 109-12.

6. Velinov, P. I. Y, Low ionosphere ionization by cosmic rays, C. R. Acad.Bulg. Sci., 1966, $19,281-84$.

7. Velinov, P. I. Y., Contribution of cosmic rays to the ionization of the lowerionosphere, C. R. Acad. Bulg. Sci., 1966, 19, 889-92.

8. Nestorov, G., Velinov P. I. Y., Effect of solar cosmic rays on the lower ionosphere. C. R. Acad. Bulg. Sci., 1966, 19, 1011-14.

9. Velinov, P. I. Y., On electron production rates in the polar cap ionosphere due to solar cosmic rays. C. R. Acad. Bulg. Sci., 1967, 20, 1275-78.

10. Velinov, P. I. Y., On the planetary distribution and energy ballance of the Cosmic Ray (CR layer in lower ionosphere, Proc. Geophys. Inst., 1967, 11, 87-102, BAS Publishers, Sofia.

11. Velinov, P. I. Y., Some results of the rate of electron production in the cosmic layer of low ionosphere. C. R. Acad. Bulg. Sci., 1967, 20, 1141-44.

12. Velinov, P. I. Y., On ionization of the ionospheric D-region by galactic andsolar cosmic rays, J. Atmos. Terr. Phys., 1968, 30, 1891-1905.

13. Velinov, P. I. Y., Solar cosmic ray ionization in the lower ionosphere, J.Atmos. Terr. Phys., 1970, 32, 139-47.

14. Velinov, P. I. Y., On variations of the cosmic ray (CR) layer in the lower ionosphere, J. Atmos. Terr. Phys., 1971, 33, 429-36.

15. Velinov, P. I. Y., Cosmic ray ionization rates in the planetary atmospheres,J. Atmos. Terr. Phys., 1974, 36, 359-62.

16. Tsagouri, I., Belehaki A., Viljanen A. et al., Progress in space weather modeling in an operational environment, Journal of Space Weather and Space Climate, 2013, 3, A17, 1-72. DOI:10.1051/swsc/2013037

17. Velinov, P. I. Y. Cosmic Ray Effects on the Lower Ionosphere, PhD Thesis, Geophys. Inst. BAS, Sofia, 1969, $161 \mathrm{p}$.

18. Velinov, P. I. Y. Study on Geophysical and Astrophysical Aspects of the Problem of Substance Ionization by Energetic Particles, DSc Thesis, Geophys, Inst. BAS, Sofia, $1975,280 \mathrm{p}$. 
19. Usoskin, I., and L. Desorgher, Ionization of the Earth's atmosphere by solar and galactic cosmic rays. Acta Geophysica, 2009, 57, 1/March, VERSITA, Warsaw, $88-101$.

20. Usoskin, I., and L. Desorgher, Solar and Galactic Cosmic Rays in the Earth's Atmosphere. In the Book: Developing the scientific basis for monitoring, modelling and predicting Space Weather, COST 724 final report (eds. J. Lilensten e), COST Office, Luxemburg, 2008, ISBN:978-92-898-0044-0, 124-32.

21. Gronoff, G., Mertens C., Lilensten J., Desorgher L., Flueckiger et al., Ionization processes in the atmosphere of Titan. III - Ionization by high- $Z$ cosmic rays, Astronomy and Astrophysics (A\&A), 2011, 529, 5, DOI:10.1051/00046361/201015675, A143-A146.

22. Velinov, P. I. Y. On the protection from cosmic rays and internal radiation belt in the space flights. In: Space exploration and applications. Proc. of First UN Conf. on Exploration and Peaceful Uses of Outer Space, Vienna, Austria, 14-27 August 1968, A/CONF. Report 34/IV, B.4, UN Publishers, New York, https://digitallibrary.un.org/record/files/A_7285-EN, 1968, 1-21.

23. Mishev, A., and Velinov P. I. Y., Ionization effect in the Earth's atmosphere during the sequence of October-November 2003 Halloween GLE events. J. Atmos. SolarTerr. Phys., 2020, 211, 105484, Elsevier, DOI:10.1016/j.jastp.2020. 105484, 1-7.

24. Velinov, P. I. Y., Altitude variations of the frequences and electron density by reflexion from the D-region. C. R. Acad. Bulg. Sci., 1965, 18, 1115-18.

25. Nestorov, G., and P. I. Y. Velinov, Electron concentration variations by long wave reflection from D-region. C. R. Acad. Bulg. Sci., 1965, 18, 1111-14.

26. Velinov, P. I. Y., Electromagnetic Field Variations of Long Radiowave Propagation in the Quiet and Disturbed Ionosphere, MSc Thesis, Geophys. Inst. BAS, Sofia, $1965,95 \mathrm{p}$.

27. Shinev, C., and Velinov P. I. Y. On the Theory of the asymmetrical antennae. Proc. Techn. Univ., Sofia, 1965, XVIII, 1, 63-72.

28. Shinev, C., and Velinov P. I. Y. On the error correction of linse antenna. Proc. Techn. Univ., Sofia, 1965, XVIII, 1, 73-80.

URL addresses:

https://www.un.org/en/observances/human-spaceflight-day https://www.esa.int/Science_Exploration/Space_Science/About_Space_Science https://en.wikipedia.org/wiki/Outline_of_space_science https://en.wikipedia.org/wiki/Astronomy\#Scientific_revolution https://www.nasa.gov/pdf/55388main_05 Space Science.pdf 


\section{ПРОГРЕСЪТ В КОСМИЧЕСКИТЕ НАУКИ И ТЕХНОЛОГИИ ВЪВ ВРЪЗКА С 60-ТА ГОДИНИНА НА ПЪРВИЯ ПОЛЕТ НА ЧОВЕКА B KOCMOCA}

\section{П. Велинов}

\section{Резюме}

На 12 април 1961 г. Юрий Гагарин възвести идването на нова космическа ера. Бързият прогрес в различните космически науки и технологии започна веднага след първия полет на човека в Космоса. Тогава се появяват принципно нови науки и технологии. В момента космическата наука обхваща широк спектьр от дисциплини. Тук е представен един общ преглед и класификация на космическите науки:

Астрономия и космическа астрономия, космология, астрофизика, космическа физика, сльнчево-земна физика, аерономия, слънчева физика, хелиосферна физика, физика на космическите лъчи, космическо време и космически климат (климата на системата Земя-Космоса), космическа дозиметрия, кос-мическа химия (или космохимия), дистанционни изследвания на Земята и планетите, планетни науки, планетна геология, астрогеология или екзогеология, екзопланетология или екзопланетна наука (наука за извънсльнчевите планетни системи), интелигентен живот във Вселената; астронавтика (или космонавтика), орбитална механика или астродинамика, космически науки за живота: биоастронавтика, космическа медицина, космическа неврология, космическа биология, биотехнологии, космическа ботаника или астроботаника, микрогравитационни изследвания при космическите полети; археоастрономия, космическа антропология, ксеноантропология (екзоантропология), космическо право, космически технологии, космическа навигация, космически комуникации, космическа архитектура, космическа логистика, космическа роботика, космически роботизирани колонии, космическа колонизация (наричана още космическо заселване или извънземна колонизация), планетна обитаемост, космическо производство, космически материали, спътникова индустрия, космически бизнес, космически туризъм, космически хардуер, космическа индустрия, космическа екология.

C помощта на тези прогресиращи космически науки човечеството започна уверено да изследва Космоса. Но тези изследвания доведоха и до множество нови технологии и приложения за подобряване на живота на хората.

Накрая отново се споменава за Юрий Гагарин и неговото космическо наследство. Той остави след себе си вдъхновяващо наследство, което и до днес все още продължава да мотивира милиони хора по целия свят. 